\title{
DEPIGMENTING AGENT MELANOTOKSIK PADA PENGOBATAN MELASMA
}

\author{
Winawati Eka Putri ${ }^{1}$, Yuli Kurniawati ${ }^{2}$, Tantawi Djauhari ${ }^{3}$ \\ ${ }^{1}$ Fakultas Kesehatan, Universitas Nahdlatul Ulama Surabaya \\ ${ }^{2,3}$ Bagian/Departemen Ilmu Kesehatan Kulit dan Kelamin FK UNSRI/RSUPMH \\ e-mail: : winawidagdo@unusa.ac.id ${ }^{1}$
}

\begin{abstract}
Human skin color is determined by melanin pigment,either eumelanin or feomelanin. Melanogenesis is a melanin synthesized process that is initiated with tirosin oxidation to DOPAquinone by tirosinase, and then auto-oxidation to DOPA and DOPAchrome. Eumelanin are formed from DOPAchrome, while pheomelanin from DOPAquinone with the presence of cysteine or gluthathione. Hyperpigmentation disorders like melasma, are difficult to treat especially in dark skinned individuals. Treatment of melasma can be topical or physical. Topical agent can use depigmenting agent, either individual or combination with other. Depigmenting agent can be melanotoxic or toxic to melanocyte which can be cell killing or cell damage. Hydroquinone, monomethyl of hydroqunone, N-acetyl-4-Scysteaminylphenol, and azelaic acid are depigmenting agents melanotoxic. Majority of those agents act as tirosinase inhibitors which cause deactivation of tirosinase. The use of those agents in combination are better to minimalize side effect of agents.
\end{abstract}

Keywords: melasma, melanogenesis, depigmenting agents, melanotoxic

Abstrak: Warna kulit manusia ditentukan oleh pigmen melanin baik eumelanin maupun feomelanin. Melanogenesis adalah proses pembentukan melanin yang diawali dengan oksidasi tirosin menjadi DOPAquinone oleh tirosinase, kemudian autooksidasi menjadi DOPA dan DOPAchrome. Eumelanin akan dibentuk dari DOPAchrome, sedangkan feomelanin akan dibentuk dari DOPAquinone dengan bantuan sistein atau gluthatione. Kelainan hiperpigmentasi, seperti melasma, sulit diobati terutama pada individu kulit gelap. Pengobatan melasma dapat berupa pengobatan topikal atau juga dengan pengobatan fisik. Obat topikal dapat menggunakan depigmenting agent baik sendiri maupun kombinasi. Depigmenting agent (DA) dapat bersifat melanotoksik atau toksik terhadap melanosit yang dapat berupa cell-killing atau kerusakan sel. Depigmenting agent melanotoksik dapat berupa hydroquinone, monomethyl of hydroqunone, N-acetyl-4-S-cysteaminylphenol, dan azelaic acid.. Sebagian besar obat tersebut bekerja sebagai inhibitor tirosinase yang dapat menyebabkan deaktivasi tirosinase. Penggunaan obat-obat tersebut secara kombinasi lebih baik untuk meminimalkan efek samping obat.

Kata kunci: melasma, melanogenesis, depigmenting agent, melanotoksik

\section{PENDAHULUAN}

Melanin merupakan pigmen yang berperan penting dalam melindungi kulit manusia dari efek berbahaya seperti radiasi sinar ultraviolet (UV), berbagai macam obat, dan bahan kimia. Pigmen ini menentukan penampakan fenotipik dan ras. Kelainan akumulasi jumlah melanin di kulit seperti melasma, dapat menjadi suatu masalah estetika bagi pasien. ${ }^{1}$ Melasma merupakan kelainan didapat yang umum terjadi terutama pada wajah, ditandai dengan patch hiperpigmentasi, simetris dengan tepi iregular. Kelainan ini disebabkan oleh peningkatan melanin dalam epidermis dan/atau dermis akibat kehamilan, kontrasepsi oral, dan pajanan sinar matahari. ${ }^{2}$

Depigmenting agent (DA) adalah obat yang dapat menyebabkan depigmentasi atau amelanosis akibat kehilangan seluruh melanin pada epidermis. ${ }^{3}$ Menurut cara kerjanya, DA terbagi menjadi beberapa kelompok yaitu kelompok inhibitor tirosinase, inhibitor transfer melanosom, 
melanocyte-cytotoxic agent, dan lainnya. ${ }^{4}$ Keberhasilan pengobatan membutuhkan kombinasi dua atau lebih obat yang bekerja dengan mekanisme berbeda untuk mencapai efek sinergis. ${ }^{1}$ Depigmenting agent melanocytecytotoxic atau melanotoksik dapat mengakibatkan kematian atau kerusakan melanosit. ${ }^{5}$ Depigmenting agent melanotoksik meliputi hydroquinone, monomethyl of hydroquinone, $\mathrm{N}$ acetyl-4-S-cysteaminylphenol,kojic acid, azelaic acid. Kelompok obat tersebut digunakan sebagai pengobatan kelainan hiperpigmentasi seperti melasma. $^{4,6}$

Tujuan pengobatan melasma adalah mengurangi proliferasi melanosit, menghambat pembentukan melanosom, dan degradasi melanosom. Pengobatan melasma epidermal lebih mudah daripada melasma dermal karena melanin terdapat pada lapisan atas kulit sehingga lebih mudah dicapai oleh obat topikal seperti DA. ${ }^{7}$ Dalam tinjauan pustaka ini akan dibahas mengenai melanogenesis, jenis, cara kerja, dan efek samping DA melanotoksik untuk pengobatan melasma.

\section{MELANOGENESIS}

Komponen warna kulit normal dipengaruhi oleh melanin, hemoglobin (oksihemoglobin dan deoksihemoglobin) dan karoten. ${ }^{8}$ Melanin dihasilkan dari tirosin melalui serangkaian reaksi berupa oksidasi terhadap DOPAquinone. Enzim yang berperan dalam reaksi tersebut adalah tirosinase, yang disintesis oleh sel dendritik yang berasal dari neural crest. Tirosinase merupakan protein dengan daerah aktif mempunyai dua atom copper yang mengikat molekul oksigen dan aktif dalam organel intraselular (melanosom) yang merupakan tempat pembentukan melanin. Melanin menumpuk di matriks protein untuk membentuk granul melanin. Pemeriksaan aktivitas enzim tirosinase pada granul melanin menunjukkan bahwa tirosinase menjadi inaktif pada melanosom yang telah termelanisasi. Hal ini dapat disimpulkan bahwa tirosinase inaktif akibat produknya sendiri. ${ }^{1}$

Melanogenesis yang terjadi dalam melanosom, dapat dilihat pada Gambar 1 dan 2, dimulai dari oksidasi tirosin menjadi DOPAquinone dengan tirosinase. DOPAquinone selanjutnya mengalami autooksidasi menjadi DOPA dan DOPAchrome. DOPA juga merupakan substrat tirosinase dan diubah lagi menjadi DOPAquinone oleh tirosinase. Dua tipe melanin yang disintesis dalam melanosom adalah eumelanin dan feomelanin. Eumelanin merupakan polimer yang tidak larut dan berwarna coklat kehitaman, sedangkan feomelanin merupakan polimer yang larut dan mengandung sulfur berwarna kuning, merah cerah. $^{10}$ Eumelanin terbentuk melalui serial reaksi oksidasi dari dihydroxyindole (DHI) dan dihydroxyindole-2carboxylic acid (DHICA), yang merupakan produk dari DOPAchrome. Feomelanin terbentuk dari DOPAquinone yang akan diubah menjadi cysteinylDOPA atau gluthathionylDOPA dengan bantuan cystein atau gluthatione. ${ }^{11}$ Individu dengan kulit gelap memiliki sebagian besar eumelanin dan sedikit feomelanin. ${ }^{7}$ Melanin bermigrasi ke ujung dendrit melanosit melalui mikrotubul dan menggunakan filamen miosin $\mathrm{V}$ dan dynein motor. Tiap melanosit berhubungan dengan sekitar 36 keratinosit membentuk epidemal melanin unit. ${ }^{4}$

Melanogenesis dapat menghasilkan intermediate reaktif yang dapat berbahaya untuk melanosit dan mempunyai efek toksik pada jaringan sekitar. Reaktivitas DOPAquinone dan orthoquinone yang terbentuk selama melanogenesis merupakan ancaman terhadap melanosit, yaitu dengan menurunkan pertahanan antioksidan sel melanogenik seperti gluthatione. Segregasi melanogenesis pada organel terikat membran dan quinone reductase serta catechol-Omethyl transferase pada sitoplasma merupakan beberapa mekanisme yang digunakan untuk melindungi melanosit dari bahaya sitotoksik. ${ }^{9}$ 


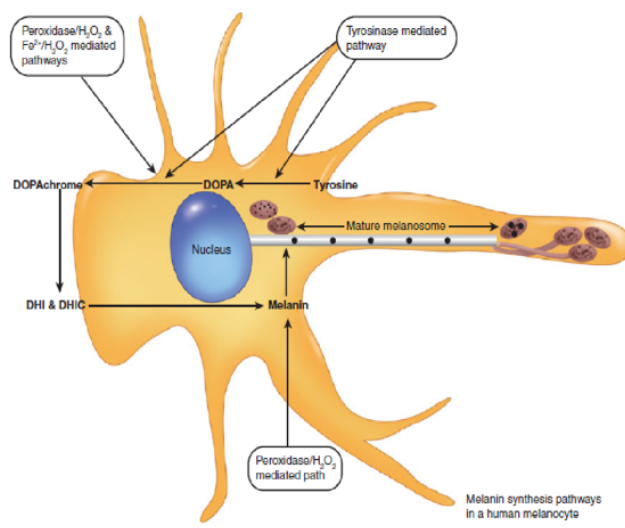

Gambar 1. Jalur sintesis melanin pada melanosit manusia $^{4}$

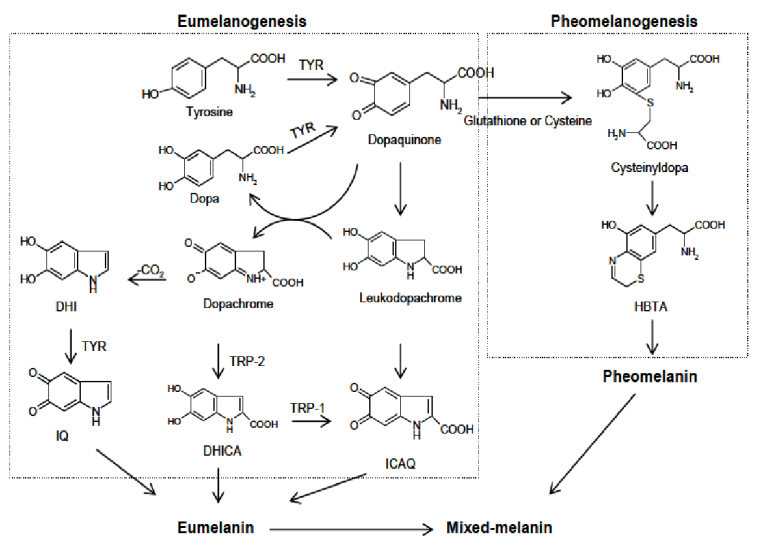

Gambar 2. Jalur biosintesis melanin. TYR, tirosin;

TRP: tirosin related protein; DOPA, 3,4-

dihydroxyphenylalanine; DHICA, 5,6-

dihydroxyindole-2-carboxylic acid; DHI, 5,6-

dihydroxyindole; ICAQ, indole-2-carboxylic acid-

5,6-quinone; IQ, indole-5,6-quinone; HBTA, 5-

hydroxy-1,4-benzothiazinylalanine. ${ }^{11}$

\section{MELASMA}

Melasma, atau yang disebut juga kloasma atau mask of pregnancy, merupakan kelainan hiperpigmentasi didapat yang kronis, ditandai dengan patch hiperpigmentasi pada area sunexposed yaitu wajah, leher, dan lengan. Kelainan ini paling sering terjadi pada wanita dengan fototipe kulit Fitzpatrick III hingga V yang tinggal pada daerah dengan pajanan sinar ultraviolet (UV) tinggi. ${ }^{12}$

Patogenesis melasma belum diketahui secara pasti, namun radiasi UV dapat menyebabkan hiperfungsi melanosit dalam kulit yang terpajan UV akan meningkatkan jumlah melanin dibandingkan dengan kulit yang tidak terpajan UV. Faktor lain yang berperan adalah predisposisi genetik atau etnis terutama yang berhubungan dengan fototipe kulit, dan hormon tertentu seperti estrogen dan progesteron. Pengaruh hormon progestron ditunjukkan pada terjadinya atau eksaserbasi penyakit selama kehamilan atau penggunaan kontrasepsi oral. Faktor pemicu lain yang berpotensi menyebabkan melasma adalah obat (obat antikonvulsan-fenitoin, fototoksik) dan penyakit tiroid autoimun. Peningkatan ekspresi $c$ kit dan stem cell factor dalam lesi epidermis dan dermis, dapat berperan dalam melasma. ${ }^{2}$

Melasma dapat ditangani secara efektif namun tidak dapat disembuhkan. Mekanisme kerja pengobatan melasma berupa meminimalkan pajanan UV, pengobatan hormonal, mencegah produksi melanin, dan mengangkat melanin. Produksi melanin dicegah dengan menghambat kerja melanosit dan menghambat transfer melanososm dari melanosit ke keratinosit. Pengangkatan melanin dapat dilakukan baik dengan modalitas fisik atau topikal. Pengobatan melasma terdiri atas tiga lini, dapat dilihat dalam tabel 1. Sarkar dkk menyatakan bahwa enam peel GA (30 dan 40\%) yang dikombinasi dengan formula Kligman memberikan respon terapi lebih baik daripada hanya menggunakan formula topikal pada pengobatan melasma. Roberts melaporkan bahwa mikrodermabrasi diikuti dengan kombinasi obat yang mengandung HQ, tretinoin, dan fluosinolon efektif untuk pasien melasma. ${ }^{13}$ 
Tabel 1. Pengobatan melasma ${ }^{13}$

\begin{tabular}{|l|l|l|l|l|}
\hline $\begin{array}{l}\text { Lini } \\
\text { pertama }\end{array}$ & $\begin{array}{l}\text { Topikal } \\
\text { SPF saat pagi } \\
\text { Triple combination } \\
\text { saat malam atau } \\
\text { monoterapi dengan } \\
\text { lightening agent 2x } \\
\text { sehari (vitamin c, } k \text { sojic } \\
\text { acid topikal) }\end{array}$ & Sistemik & Fisik & \\
\hline Lini kedua & $\begin{array}{l}\text { SPF saat pagi } \\
\text { dan HQ saat malam }\end{array}$ & & $\begin{array}{l}\text { Mikrodermabrasi } \\
\text { tiap 2 pekan untuk } \\
\text { 6 sesi } \\
\text { Peel asam salisilat } \\
\text { tiap 2-4 pekan untk } \\
\text { 3-6 peel }\end{array}$ & $\begin{array}{l}\text { Dapat } \\
\text { menggunakan HQ } \\
\text { sebagai monoterapi } \\
\text { atau triple } \\
\text { combination } \\
\text { (Triluma } \AA \text { ) }\end{array}$ \\
\hline Lini ketiga & SPF saat pagi & & $\begin{array}{l}\text { Laser fraksional } \\
\text { resurfacing pada } \\
\text { tipe kulit I-IV }\end{array}$ & $\begin{array}{l}\text { setelah pigmentasi } \\
\text { clear tidak selama } \\
\text { IPL (efektif pada } \\
\text { tipe kulit orang } \\
\text { Asia) }\end{array}$ \\
\hline
\end{tabular}

\section{DEPIGMENTING AGENT}

\section{MELANOTOKSIK}

Sebagian besar senyawa DA menghasilkan efek multipel yang mengakibatkan penurunan melanisasi. Mekanisme kerja DA dapat berupa inhibisi tirosinase, stimulasi turnover keratinosit, reduksi transfer melanosom, interaksi dengan copper, inhibisi maturasi melanosom, inhibisi protease-activated receptor 2 , inhibisi plasmin, reduksi melanocyte-stimulating hormone-induced melanin production. ${ }^{12}$

Jimbow dkk pada tahun 1971 menyatakan bahwa produksi melanin berlebihan menyebabkan toksisitas melanosit sehingga dapat membunuh melanosit. Sitotoksisitas dari melanogenesis terutama dari pembentukan o-quinone (DOPAquinone) sebagai intermediate yang dimediasi oleh tirosinase.(jimbow,1996) Jimbow dkk melaporkan bahwa kerusakan sel berupa degradasi organela membran, clumping granula melanin, vakuolasi sitoplasma. ${ }^{5}$

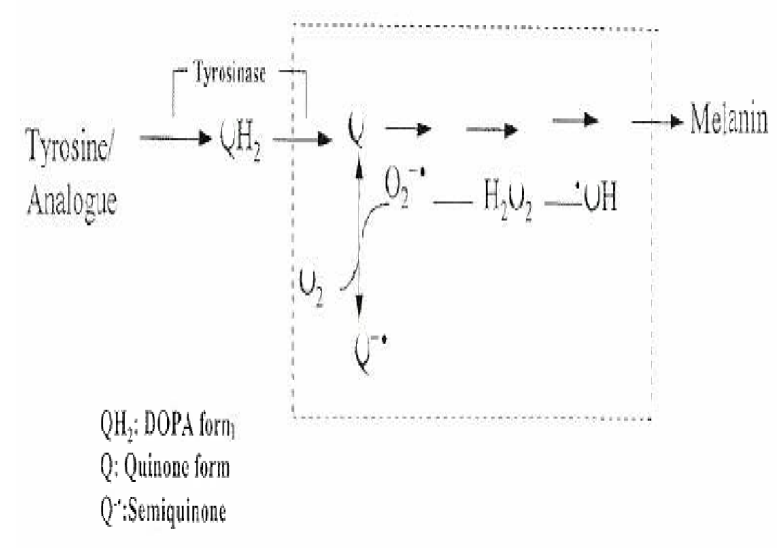

Gambar 3. Produksi radikal quinone dan semiquinone sitotoksik (radikal oksi dan hidroksi) selama perubahan tirosin menjadi DOPA dan kemudian menjadi DOPAquinone dengan adanya tirosinase. ${ }^{14}$

\section{Hydroquinone}

Hydroquinone (1,4-dihydroxybenzene, $\mathrm{HQ})$ merupakan senyawa fenol yang bekerja pada melanosit melalui tirosinase aktif. Hydroquinone telah menjadi baku emas dalam pengobatan hiperpigmentasi selama lebih dari 50 tahun. ${ }^{15}$ Hydroquinone telah berhasil digunakan untuk 
segala bentuk hiperpigmentasi epidermal seperti melasma dan hanya komponen epidermal yang merespon baik terhadap penggunaan $\mathrm{HQ} .{ }^{16}$ Senyawa HQ dapat ditemukan dalam gandum, teh, berries, beer, dan kopi, namun didetoksifikasi di liver menjadi komponen inert. ${ }^{15}$

Hydroquinone bekerja dengan menghambat tirosinase dan mencegah perubahan tirosin menjadi DOPA. ${ }^{17}$ Hydroquinone juga bekerja menghambat pigmentasi dengan modifikasi pembentukan melanosom atau menghambat sintesis DNA dan RNA dengan degradasi melanosom serta destruksi melanosit. ${ }^{15,18}$ Hydroquinone mempunyai peran sitotoksik (cell killing atau kerusakan sel) pada melanosit yang disebabkan oleh mekanisme oksidasi radikal bebas. Pembentukan radikal bebas berpotensi merusak melanosit itu sendiri atau di dekatnya atau struktur fisik sel. ${ }^{19}$

Efektivitas HQ berhubungan langsung dengan konsentrasi sediaan, vehikulum yang digunakan, dan komposisi kimia produk akhir. Hydroquinone 4\% paling sering digunakan oleh dermatolog karena sangat efektif namun dapat menyebabkan efek iritan bermakna. ${ }^{18}$ Obat ini digunakan dua kali sehari dan biasanya dalam jangka waktu lama, kisaran tiga hingga enam pekan agar efek obat terlihat. ${ }^{16}$ Konsentrasi HQ di atas 5\% meningkatkan risiko efek samping tanpa meningkatkan efikasi. Keberhasilan preparat ini terbatas pada epidermis. Preparat ini mudah teroksidasi pada $\mathrm{pH}>6$ dan kehilangan potensi setelah 2 bulan. ${ }^{20}$

Penggunaan HQ dalam kosmetik telah dilarang oleh European Committee karena bahaya penggunaan jangka panjang. ${ }^{15,18}$ Okronosis eksogenosa merupakan efek samping utama dari $\mathrm{HQ}$, yang dapat terjadi pada individu yang menggunakan HQ dalam jangka panjang, yaitu satu tahun atau lebih, dan terpajan oleh sinar matahari. ${ }^{16}$ Efek samping lain penggunaan HQ berupa dermatitis kontak alergi dan iritan, perubahan warna kuku, dan hipermelanosis pasca inflamasi. Efek samping tersebut bersifat sementara dan mengalami perbaikan bila HQ dihentikan. ${ }^{18}$

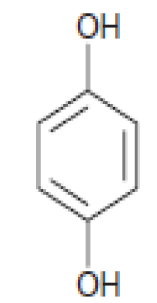

Hydroquinone

\section{Gambar 4. Struktur kimia hydroquinone ${ }^{4}$}

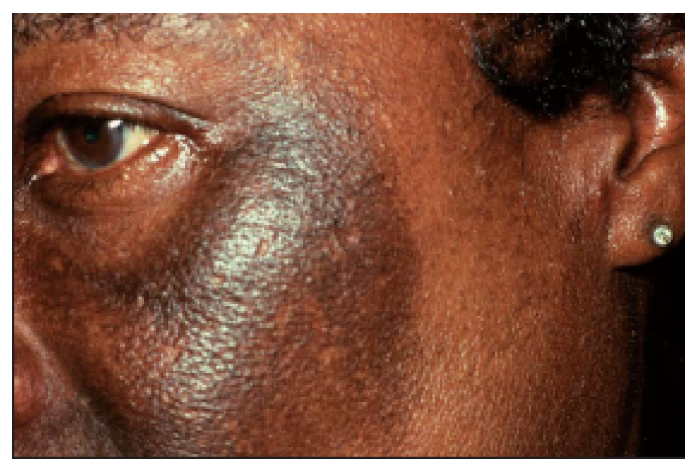

Gambar 5. Okronosis eksogenosa 2

\section{Monomethyl of hydroquinone}

Monomethyl of hydroquinone (MMEH) atau 4-hidroxyanisole (4-HA) merupakan substrat tirosinase dan berperan sebagai inhibitor kompetitif melanogenesis. ${ }^{4}$ Obat ini dioksidase oleh tirosinase dan menghasilkan efek melanositotoksik yang kuat. $^{18}$ Pembentukan quinone akibat oksidasi oleh tirosinase mengakibatkan destruksi sel pigmen dan depigmentasi kulit. ${ }^{15}$

Monomethyl of hydroquinone digunakan di Perancis dengan konsentrasi $8-10 \%$ sebagai pengobatan melasma dan hipermelanosis pasca inflamasi. ${ }^{18} \quad$ Penggunaan $\mathrm{MMEH}$ yang dikombinasi dengan tretinoin $0,01 \%$ dapat menghambat produksi melanin dan mendapatkan hasil lebih baik daripada bila masing-masing obat digunakan sendiri. ${ }^{16}$ 
Efek samping MMEH berupa dermatitis kontak iritan dan alergi, hipermelanosis pasca inflamasi, dan leukoderma en confetti pada daerah yang diobati. ${ }^{18}$ Studi lain oleh Moridani mendapatkan bahwa MMEH yang diberikan pada tikus dapat menyebabkan hepatotoksisitas. Hepatotoksisitas ini dapat dilihat dengan peningkatan tujuh kali lipat transaminase plasma dalam 24 jam. ${ }^{19}$<smiles>COc1ccc(O)cc1</smiles>

\section{Gambar 5. Struktur kimia Monomethyl of hydroquinone $e^{4}$}

\section{$\mathrm{N}$-acetyl-4-S-cysteaminylphenol}

$N$-acetyl-4-S-cysteaminylphenol merupakan senyawa melanositotoksik yang terdiri dari fenol dan cathecolic dengan kemampuan depigmentasi. ${ }^{4,21}$ Senyawa ini berfungsi sebagai substrat tirosinase dan secara selektif mentarget sel dengan sintesis melanin aktif. ${ }^{6}$ Depigmentasi akibat penggunaan obat ini disebabkan karena penurunan jumlah melanosit aktif dan jumlah melanosom yang ditransfer ke keratinosit. ${ }^{21}$

Pada satu studi yang dilakukan pada 12 pasien melasma dilaporkan pigmentasi berkurang secara bermakna dengan hasil lebih jelas pada 2-4 pekan setelah penggunaan $\mathrm{N}$-acetyl-4-Scysteaminylphenol $4 \%$ satu kali sehari. ${ }^{4,21} \mathrm{~N}$ acetyl-4-S-cysteaminylphenol lebih stabil dan kurang iritasi daripada HQ. ${ }^{6}$ Senyawa ini telah diuji pada sejumlah kecil pasien melasma dan didapatkan perbaikan atau complete clearing dengan efek samping minimal pada $75 \%$ pasien. Namun demikian, senyawa ini tidak digunakan secara luas karena uji klinis untuk evaluasi keamanan serta efikasi belum tersedia. ${ }^{18}$

\section{Azeleic acid}

Azelaic acid (AZA) merupakan dicarboxylic acid dengan sembilan atom karbon yang diisolasi dari biakan Pityrosporum ovale. Pityrosporum ovale akan mengoksidasi asam lemak tak jenuh menjadi dicarboxylic acid yang menghambat tirosinase. ${ }^{4}$

Azelaic acid menghasilkan efek anti proliferasi dan sitotoksik terhadap melanosit dengan menghambat oksidoreduktase dan sintesis DNA mitokondria pada melanosit yang sangat aktif atau abnormal. ${ }^{6,11,22}$

Obat ini pertama kali digunakan sebagai pengobatan lentigo maligna namun tidak digunakan lagi karena tidak menghancurkan malignansi yang menyebar. Saat ini AZA digunakan sebagai pengobatan melasma yang tersedia dalam konsentrasi $20 \%$ dan digunakan dua kali sehari. Pengobatan harus dilanjutkan hingga beberapa bulan. ${ }^{16}$ Pada satu studi selama enam bulan oleh Sarkar dkk pada 132 wanita Asia dengan melasma, pengobatan dengan AZA selama rerata empat tahun menyebabkan pencerahan yang lebih banyak pada lesi pigmentasi disertai dengan pengurangan ukuran lesi. ${ }^{23}$ Krim AZA 20\% terbukti lebih efektif daripada krim HQ 2\% namun didapatkan efikasi serupa dengan HQ 4\% setelah 24 pekan pengobatan melasma. ${ }^{6,18,24}$

Penggunaan AZA relatif aman walaupun dapat terjadi iritasi ringan. ${ }^{24}$ Efek samping paling sering dijumpai berupa eritem transien, dan iritasi kulit ditandai dengan skuama, gatal, rasa seperti terbakar yang akan menghilang setelah penggunaan 2-4 pekan. ${ }^{18,23}$

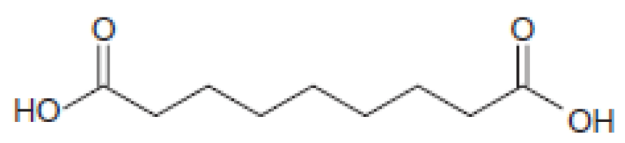

Gambar 8. Struktur kimia azeleic acid ${ }^{4}$

Kombinasi pengobatan

Tujuan kombinasi pengobatan melasma adalah menambah efikasi dengan menggabungkan 
bahan aktif dengan mekanisme kerja berbeda untuk menghasilkan efek sinergis, untuk memperpendek durasi terapi, dan mengurangi risiko efek samping obat. ${ }^{18}$

Formula Kligman. Pengobatan kombinasi paling dikenal adalah formula Kligman. ${ }^{18}$ Pada tahun 1975 Kligman melaporkan satu formula yang mengandung HQ $5 \%$, deksametason $0,1 \%$, dan tretinoin $0,1 \%$ yang efektif dalam pengobatan melasma, efelid, dan hiperpigmentasi pasca inflamasi. Preparat ini menjadi gelap akibat oksidasi bila disimpan selama lebih dari satu bulan. Tretinoin berfungsi sebagai penguat penetrasi HQ dalam epidermis. Selanjutnya, tretinoin meningkatkan turnover epidermal, sehingga memfasilitasi dispersi melanin dalam keratinosit dan juga pengangkutan melanin dari korneosit. Deksametason mengurangi iritasi dan inflamasi akibat HQ dan/atau tretinoin dan sintesis melanin dengan menghambat aktivitas metabolik. ${ }^{18}$ Kligman dan Willis membuat hipotesis bahwa kortikosteroid topikal menekan produksi melanin tanpa merusak melanosit dengan menekan fungsi biosekresi dan sekretori dalam melanosit. ${ }^{24}$ Depigmentasi terjadi lebih cepat, dimulai dalam tiga pekan setelah penggunaan formula dua kali sehari. Formula lain yang lebih stabil mengandung HQ $4 \%$, tretinoin $0,05 \%$, dan fluosinolone asetonide $0,01 \%$. Dua uji terkontrol buta ganda acak multisenter menunjukkan keamanan dan efikasi dari pengobatan kombinasi ini pada pasien melasma moderat hingga berat. Setelah delapan pekan pengobatan, pengurangan melasma sebanyak $75 \%$ didapatkan pada lebih dari $75 \%$ pasien. $^{18}$

Azelaic acid dan tretinoin. Kombinasi rejimen AZA 20\% dengan tretinoin topikal 0,05\% menghasilkan kulit cerah lebih cerah dan nyata selama fase awal pengobatan. Azelaic acid 20\% juga dapat digabung dengan losion glycolic acid $20 \%$ yang sama efektif dengan krim HQ 4\%. ${ }^{18}$
Hydroquinone dan kojic acid. Kojic acid $2 \%$ dalam gel, glycolic acid $10 \%$ dan HQ $2 \%$ mengobati melasma epidermal dalam 12 pekan pengobatan. Kojic acid 1-4\% dikombinasi dengan tretinoin, HQ, dan/atau kortikosteroid atau glycolic acid akan bekerja sinergis. ${ }^{18}$

Formula Westerhof. Kombinasi dari $\mathrm{N}$ acetylcystein 4,7\% (NAC), HQ 2\%, dan triamsinolon asetonide $0,1 \%$ terbukti efektif dalam pengobatan melasma. Mekanisme kerja NAC belum sepenuhnya diketahui. N-acetylcystein menghasilkan efek inhibitor tirosinase yang lebih memicu terjadi feomelanogenesis daripada eumelanogenesis sehingga menghasilkan warna kulit lebih cerah. ${ }^{18}$

\section{Phenol}

Phenol, atau juga dikenal sebagai asam karbolik, merupakan presipitan protein yang menyebabkan denaturasi cepat dan koagulasi keratin permukaan yang ekstrim. ${ }^{26}$ Phenol dahulu digunakan sejak lama sebagai pengobatan melasma, namun sudah tidak digunakan lagi karena toksik terhadap melanosit. ${ }^{27}$

Kligman dkk pada tahun 1985 melakukan pengamatan histologik jangka panjang pada phenol peeling di wajah. Depigmentasi akibat phenol disebabkan bukan karena destruksi melanosit namun kelainan sintesis melanin, yang terjadi sangat lama (20 tahun atau lebih). Phenol yang merupakan inhibitor peroksidase, bekerja selama sintesis melanin dan mneyebabkan pengurangan polimerisasi intermediate melanogenik. Phenol peeling menyebabkan melanopenia, melanositopenia, dan dispersi melanin dalam keratinosit. ${ }^{27}$

Formula Baker-Gordon merupakan formula phenol standar yang terdiri dari $3 \mathrm{ml}$ USP phenol cair, $2 \mathrm{ml}$ air, 8 tetes sabun cair, 3 tetes croton oil. Croton oil berperan dalam iritasi kulit, sedangkan sabun cair sebagai surfaktan dan emulsifier untuk membantu penetrasi. Kombinasi obat ini 
digunakan untuk wrinkle dan kelainan pigmentasi, serta menyebabkan kerusakan pada dermis yaitu retikular dermis atas. Phenol didetoksifikasi di liver dan diekskresi oleh ginjal. Dosis toksik phenol dapat merusak liver dan ginjal serta menekan respirasi dan miokardium. ${ }^{26}$

\section{KESIMPULAN}

Depigmenting agent banyak digunakan sebagai pengobatan kelainan hiperpigmentasi, salah satunya melasma. Menurut cara kerjanya DA terbagi menjadi beberapa kelompok yaitu kelompok inhibitor tirosinase, inhibitor transfer melanosom, melanocyte-cytotoxic agent, dan lainnya. Depigmenting agent melanotoksik atau mengakibatkan cell-killing atau kerusakan melanosit meliputi hydroquinone, monomethyl of hydroquinone, N-acetyl-4-S-cysteaminylphenol, phenol, kojic acid, azelaic acid. Sebagian besar obat tersebut bekerja juga sebagai inhibitor tirosinase. Pengobatan melasma yang paling baik berupa kombinasi dari beberapa kelompok obat sehingga dicapai hasil efektif dengan efek samping minimal.

\section{DAFTAR PUSTAKA}

Solano F, Briganti S, Picardo M, Ghanem G. Hypopigmenting agents: an updated review on biological, chemical and clinical aspects. Pigment Cell Res 2006; 19: 550-71.

Chang MW. Dysorders of hyperpigmentation. In: Bolognia JL, Jorizzo JL,Rappini RP, Schaver JV, editors. Dermatology. $2^{\text {nd }}$ ed. Edinburg: Mosby; 2008. p.939-63.

Nordlund JJ, Cestari T, Grimes P, Chan H, Ortonne JP. A more precise lexicon for pigmentation, pigmentary disorders, and chromatic abnormalities. In: Nordlund JJ, Boissy RE, Hearing VJ, King RA, Oetting WS, Ortonne JP, ditors. The Pigmentary System:
Physiology and Pathophysiology, $2^{\text {nd }}$ ed. London: Blackwell Publishing Ltd; 2006. p.499-503

Baumann $L$ dan Allemann IB. Depigmenting agents. In: Baumann L.

Cosmetic Dermatology, Principle and Practice. $2^{\text {nd }}$ ed. United States: McGraw Hill; 2009. p.279-91

Jimbow K,obata $H$, pathak MA. Fitzpatrick TB:mechanism of depigmentation

by hydroquinone. J Invest Dermatol 1974; 62:436-49

Katsambas AD, Stratigos AJ. Depigmenting and bleaching agents: coping with hyperpigmentation. Clinics in Dermatology 2001; 1: 483-8

Baumann L, Saghari S. Skin pigmentation and pigmentation disorders. In: Baumann L. Cosmetic Dermatology, Principle and Practice. $2^{\text {nd }}$ ed. United States: McGrawHill; 2009. p.98-108

Ortonne JP, Nordlund JJ. Mechanisms that cause abnormal skin color. In: Nordlund JJ, Boissy RE, Hearing VJ, King RA, Oetting WS, Ortonne JP, editors. The Pigmentary System: Physiology and Pathophysiology, $2^{\text {nd }}$ ed. London: Blackwell Publishing Ltd; 2006. p.52136

Land EJ, Ramsden CA, Riley PA. Toxicological aspects of melanin and melanogenesis. . In: Nordlund JJ, Boissy RE, Hearing VJ, King RA, Oetting WS, Ortonne JP, editors. The Pigmentary System: Physiology and Pathophysiology, $2^{\text {nd }}$ ed. London: Blackwell Publishing Ltd; 2006. p.35494

Gillbro JM, Olsson MJ. The melanogenesis and mechanisms of skin-lightening agents-existing and new approaches. Int J Cosm Sci 2011; 33: 210-21 
Chang Te Sheng. An update review of tirosinase inhibitors. Int. J Mol Sci 2009; 10: $2440-75$

Sheth VM, Pandya AG. Melasma: A comprehensive update. J Am Acad Dermatol 2011; 65:699-714

Roberts WE. Melasma. in: Kelly AP, Taylor SC. Dermatology for skin color.United State: McGraw Hill; 2009. p.332-6

Jimbow K. Current topics in melanin pigmentation and its application to the management and patophysiology of pigmentary diseases. Dermatol sinica 1996; 14:1-14.

Ebanks JP, Wickett RR, Boissy RE. Mechanisms regulating skin pigmentation: The rise and fall of complexion coloration. Int. J. Mol. Sci 2009; 10: 4066-87

Halder RM, Nordlund JJ. Topical treatment of pigmentary disorders. In: Nordlund JJ, Boissy RE, Hearing VJ, King RA, Oetting WS, Ortonne JP, editors. The Pigmentary System: Physiology and Pathophysiology, $2^{\text {nd }}$ ed. London: Blackwell Publishing Ltd; 2006. p.116574

Grimes PE, 2006. Pharmacological Agents for Pigmented Skins. In: Halder RM. Dermatology and dermatological therapy for pigmented skin. London: Taylor and Francis group. p. 274-87

Passeron T, Ortonne JP, 2010. Pigmentation: dyschromia. In: Barran R, Maibach HI. Textbook of cosmetic dermatology. 4th ed. London: Informa healthcare; 2010. p.311-29

Moridani MY, Cheon SS, Khan S, O'Brien PJ. Metabolic activation of 4hydroxyanisole by isolated rat hepatocytes. The American Society for
Pharmacology and Experimental Therapeutics 2002; 30: 1063-9

Nilesh morar, ncoza Dlova. Topical hydroquinone. in: Kelly AP, Taylor SC. Dermatology for skin color. United State: McGraw Hill; 2009. p. 475-8.

Rendon M, Berneburg M, Arellano I, Picardo M. Treatment of melasma. J Am Acad Dermatol 2006;54: S272-81

Brenner M, Hearing VJ, 2008. Modifying skin pigmentation - approaches through Intrinsic biochemistry and exogenous agents. Drug Discov Today Dis Mech 2008; 5(2): e189-99

Parvez S, Kang M, Chung HS, Cho C, Hong $M C$, Shin MK, Bae H. Survey and mechanism of skin and lightening agents. Phytother Res 2006; 20: 921 34

Jones JB, 2004. Topical therapy. In: Burns T, Breathnach S, Cox N, Griffiths C. Rook's Textbook of Dermatology ed 7 vol 3. United State: Blackwell Publishing; 2004. p.1-52

Perrotti JA. Cutaneous resurfacing: chemical peeling, dermabrasion, and laser resurfacing. In: Thorne $\mathrm{CH}$. Grabb and Smith's Plastic Surgery, $6^{\text {th }}$ ed. London: Lippincott Williams \& Wilkins, 2007. p.459-67

Attia EAS, Samahy MHE, Mahmoud SA. Cryotherapy versus phenol chemical peeling for solar lentigines: a clinical, histologic, immunohistochemical and ultrastructural study. J Egypt Women Dermatol Soc 2010; 7: 87-96 